\title{
PSIHOLOGIJA UČENJA IN POUKA Dr. Barica Marentič Požarnik
}

oktorica psihologije in pedagogike Barica Marentič Požarnik je spet obogatila zakladnico slovenske psihološke in pedagoške literature $z$ novo knjigo. Tako kot se je izkazalo že pri prejšnjih delih, bo tudi nova knjiga zanimiva za strokovnjake različnih strok, saj celostno obravnava vprašanja učenja, izobraževanja in poučevanja, upoštevaje najnovejša strokovna in znanstvena spoznanja. Knjiga je namenjena vsem, ki se tako ali drugače ukvarjajo z izobraževanjem - učiteljem različnih vrst in stopenj izobraževanja, pedagogom, andragogom, svetovalcem in drugim pa tudi tistim, ki se učijo in izobražujejo, in je zrcalo novih raziskovalnih spoznanj o psihologiji učenja, ki govorijo o spremenjenih vlogah učenja in poučevanja ter učitelja in učečega se v učnem procesu. Izredno zanimiva bo za vsakogar, ki želi svoja spoznanja s tega področja prevetriti, posodobiti in dopolniti.

Posebna odlika knjige je ta, da avtorica ne govori le o novih pristopih, temveč jih v knjigi tudi uporablja: tistim, ki bi si radi pridobili še bolj poglobljeno znanje $\mathrm{z}$ določenega področja, pomaga ob prebiranju in študiju s tem, da jih s sprotnimi navedbami dodatnih študijskih virov usmerja $\mathrm{k}$ nadaljnjemu, poglobljenemu in širšemu študiju. Posebnost je tudi organiziranost in struktura knjige, ki omogočata, da vsebine izbiramo na nov, interaktivni način, tako lahko smiselno prehajamo s teme na temo, preberemo neznane pojme in jih povezujemo $\mathrm{z}$ drugimi področji in teorijami. Nova znanja lahko na podlagi ponujenih spodbud za samostojni premislek ali dejavnost povežemo z našimi izkušnjami in struk- turo znanja, ki jo že imamo, ter tako zapolnjujemo primanjkljaje po lastnih potrebah.

Besedilo je razdeljeno na 21 poglavij, ki so sproti označena glede na njihovo povezanost po sorodnosti pojmov.

$\mathrm{V}$ prvem poglavju se avtorica osredini na vprašanje, kaj je učenje, in nam v nadaljevanju ponuja kratek, a dovolj poglobljen sprehod skozi labirint teorij učenja; sproti nas spodbuja $\mathrm{k}$ iskanju teoretičnih pojasnil različnih psiholoških pojmov, ki jih lahko poiščemo na drugih mestih $\mathrm{v}$ knjigi.

Sledi poglavje, v katerem avtorica pojasnjuje nevrofiziološke osnove učenja - pomen povezanega delovanja možganskih hemisfer, preučevanje zmožnosti učenja $v$ različnih stanjih zavesti ob različnih stopnjah možganske aktivnosti, zorenje in učenje $v$ razvoju posameznika, kar avtorica podkrepi tudi z razmišljanjem različnih teoretikov o povezanosti obeh fenomenov. V nadaljevanju pojasnjuje nižje in višje oblike učenja - psihomotorično učenje in učenje $z$ opazovanjem, besedno-simbolno učenje (vrste besednega učenja, razvoj in vloga govora, besedno učenje in smiselnost idr.) in učenje pojmov ter zakonitosti (na primer, kaj so pojmi in kako jih tvorimo, poučevanje pojmov in drugo), o čemer govorijo tretje, četrto in peto poglavje.

Šesto poglavje nam sistematično in celostno predstavi pomnjenje in pozabljanje pri otrocih, mladostnikih, odraslih $\mathrm{v}$ procesu učenja. Avtorica govori o pomenu preučevanja pomnjenja, o teorijah pomnjenja, o teorijah informacij ter večfaznem modelu spomina in strategijah za izboljšanje pomnjenja. 
V naslednjih dveh poglavjih se lahko seznanimo $\mathrm{z}$ učenjem kot reševanjem problemov in povezanostjo ustvarjalnosti ter učenja. V sedmem poglavju govori predvsem o tem, kaj so sestavine ustvarjalnega mišljenja in kako spodbujati ustvarjalnost $\mathrm{v}$ učnem procesu. V nadaljevanju avtorica pojasnjuje vrste učnega transfera in možnosti za vsebinski ter proceduralni transfer.

Zanimivo je poglavje o učenju stališč in vrednot, v katerem med drugim spoznavamo psihološke teorije moralnega razvoja ter modele spodbujanja moralnega učenja.

$\mathrm{V}$ enajstem poglavju piše avtorica o celostnih pristopih $\mathrm{k}$ učenju, ki se še posebej uveljavljajo pri izobraževanju odraslih. Omenimo na primer sugestopedijo, ki se uspešno uporablja pri poučevanju tujih jezikov, in preučevanje metod ter postopkov in pomena izkušenjskega učenja. V knjigi so v nadaljevanju opisani dejavniki in metode uspešnega učenja in pojmovanje o umskih sposobnostih ter učenju. Avtorica pojasni različne pristope $\mathrm{k}$ razumevanju inteligentnosti in pojasnjuje sposobnosti v odraslosti ter starosti.

$\mathrm{V}$ knjigi so prikazani tudi izredno zanimivi izsledki o upoštevanju kvalitativnih razlik pri posameznikovem spoznavanju in učenju - stilov spoznavanja, spoznavne strukture in učenja, pri čemer so podrobneje opisani stili zaznavanja, stili spoznavanja, stili učenja in napotki, kako naj bi učitelj upošteval spoznanja o različnih stilih. V nadaljevanju so opisana spoznanja o najpomembnejših učnih strategijah in individualnih razlikah $\mathrm{v}$ pristopih $\mathrm{k}$ učenju, ki naj bi jih poznal vsak učeči se.

$\mathrm{V}$ zadnjem delu knjige avtorica pojasnjuje področje motivacije; naniza pregled teoretskih pogledov na učno motivacijo, razčleni vpliv notranje in zunanje motivacije. Poglavje, ki sledi, namenja čustvenim in osebnostnim dejavnikom učenja, precej pozornosti pa namenja vplivu napetosti ter anksioznosti v procesu učenja in možnostim za nji-

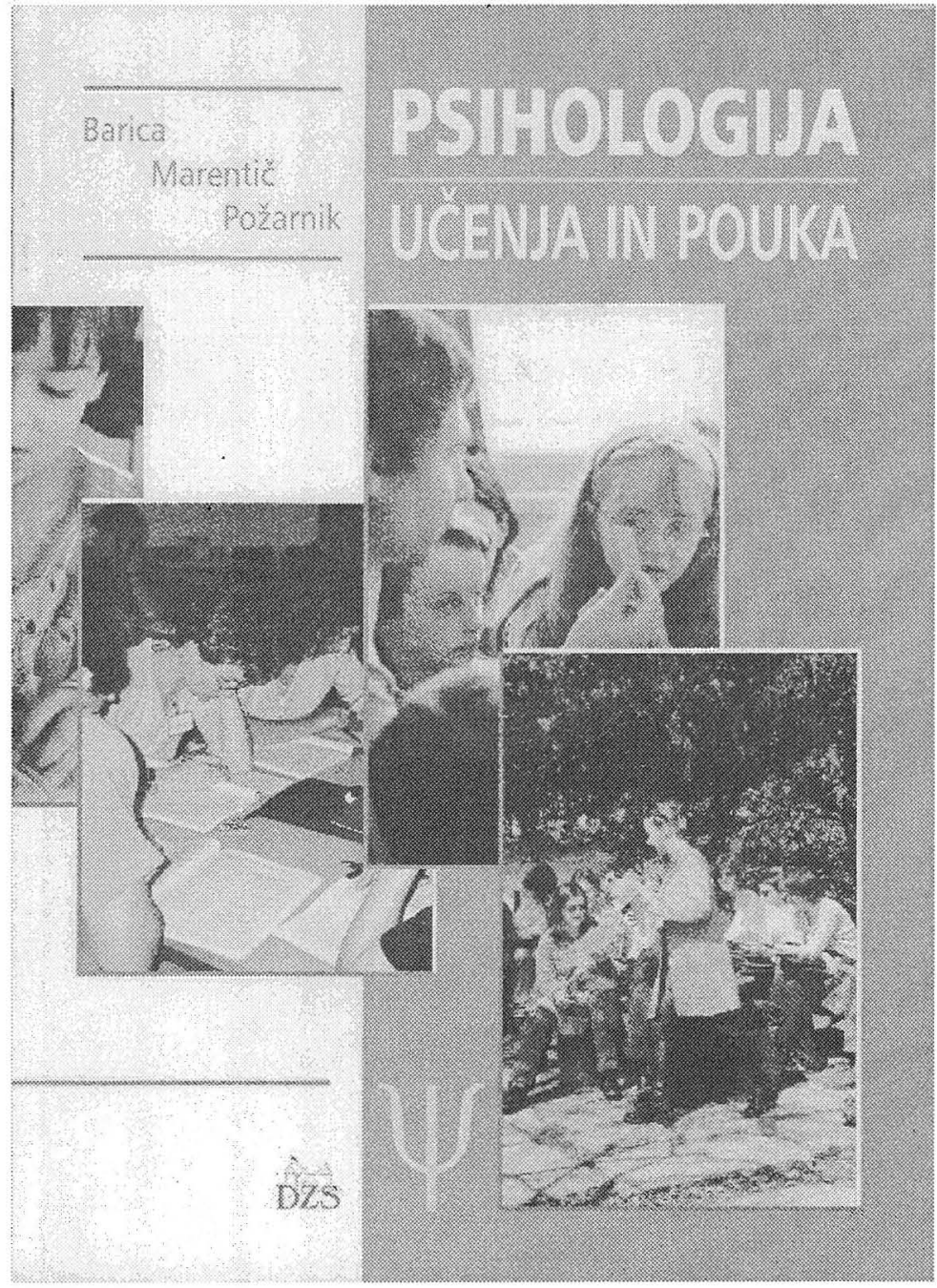

hovo zmanjševanje, pa tudi za zmanjševanje stresa, anksioznosti in poklicne izgorelosti učiteljev. Govori tudi o socialnopsiholoških dejavnikih učenja in poudarja pomen komunikacije ter vlogo učitelja pri navezovanju odnosov in komunikacijskih vzorcev v učnem procesu.

Posebno poglavje je namenjeno osebam s posebnimi potrebami.

Na koncu je še pomembno poglavje o namenu preverjanja in ocenjevanja znanja, o vrstah in oblikah preverjanja ter ocenjevanja in ovrednotenju različnih pristopov za kvalitetno učenje. 
Avtorica končuje knjigo z razmišljanjem o učenju za prihodnost, ki naj bo inovativno ter vseživljenjsko in naj zajema različne razsežnosti učenja in bivanja.

Hkrati z zahtevami po uveljavljanju strategije vseživljenjskosti učenja in izobraževanja se uresničuje tudi potreba po stalnem učenju, učenju v vseh obdobjih življenja. Sočasno z željo in potrebo po dejavnosti ter odgovornosti odraslih v procesu učenja pa postajajo vse pomembnejša tudi vprašanja o njihovih različnih potrebah in interesih ter sposobnostih za učenje.

Knjiga nam daje možnost, da o različnih ter o skupnih značilnostih in potrebah mladih in odraslih pri učenju poglobljeno premislimo ter z novimi spoznanji dopolnimo naše prejšnje znanje in/ali potrdimo naša prepričanja. Avtorica nas stalno opozarja tudi na značilnosti odraslih v razmerju do različnih psiholoških teorij, pojmov in spoznanj. Spričo tega bo knjiga $\mathrm{v}$ veliko pomoč tistim učiteljem, ki se ukvarjajo z otroki in mladino, in tudi tistim, ki se ukvarjajo z izobraževanjem odraslih.

S svojo novo knjigo Psihologija učenja in pouka je plodovita avtorica pomembno dopolnila svoj opus, ki je v zadnjih letih segal zlasti na področja učenja (spomnimo se knjige Stili raznolikosti - stili spoznavanja, učenja in mišljenja, ki jo je izdala s soavtoricama Lidijo Magajna ter Cirilo Peklaj) in visokošolske didaktike (knjiga Za boljšo kakovost študija s soavtorjem Bogomirjem Mihevcem). Njeno zadnje delo nam omogoča, da se naučimo veliko novega, a tudi to, da vnovič razmislimo o strategijah, ki jih uporabljamo pri delu z odraslimi, mladostniki ali otroci $v$ učnem procesu, o vzrokih za naše ravnanje in možnostih, ki jih še lahko izrabimo, in da naše izkušnje vnovič potrdimo tudi pri spoznavanju znanstvene teorije in drugih spoznanj s področja psihologije.

Knjiga je izšla junija 2000 pri Državni založbi Slovenije. 